\title{
Single platform cord blood CD34
}

\section{Vasiliki E. Kalodimou ${ }^{1 *}$}

${ }^{1}$ Lab Director at Flow Cytometry-Research \& Regenerative Medicine, IASO Maternity \& Research Hospital, Athens-Greece
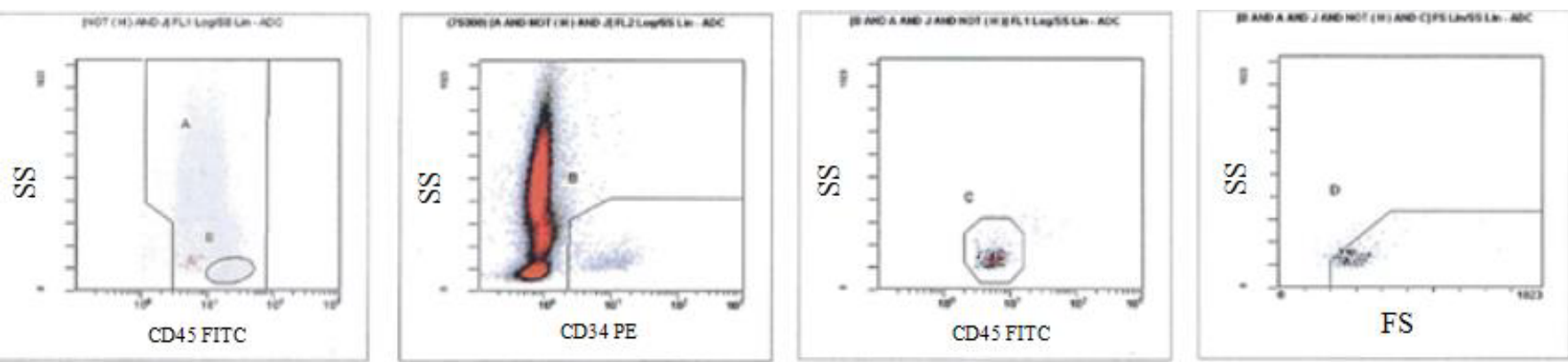

\section{Fresh cord blood}
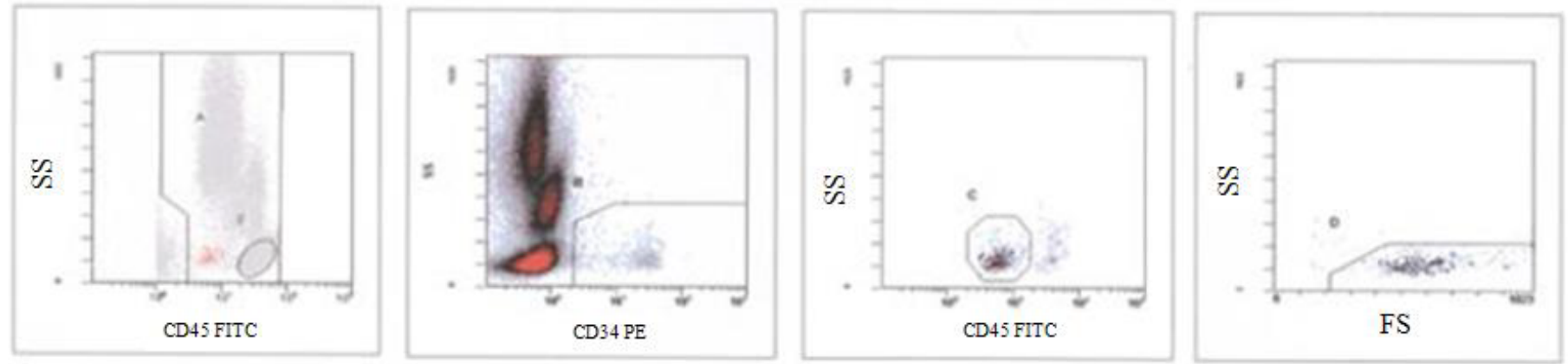

\section{Thawed CB (lyse no wash)}

Figure 1. Single Platform Cord Blood CD34+ Enumeration: Addition of fluorescent beads of known concentration allows calculation of absolute numbers of CD34+ cells directly from the flow cytometer in fresh and thawed cord blood units.

NOTE: Contaminate an antibody with another antibody will affect the staining profiles, OR bacterial contamination of sheath fluid will result to an increase in the events of flow cytometer.

Copyright: (C2017 Kalodimou VE. This is an open-access article distributed under the terms of the Creative Commons Attribution License, which permits unrestricted use, distribution, and reproduction in any medium, provided the original author and source are credited.
Correspondence to: Vasiliki E. Kalodimou, Lab Director at Flow CytometryResearch \& Regenerative Medicine, IASO Maternity \& Research Hospital, Athens-Greece, E-mail: kalodimou@yahoo.gr

Received: May 10, 2017; Accepted: May 22, 2017; Published: May 25, 2017 